\title{
KARAKTERISTIK KONSUMEN DALAM PEMBELIAN DAGING SAPI DI KOTA MANADO \\ (STUDI KASUS DI TRANSMART CARREFOUR STAR SQUARE MANADO)
}

\author{
Anastasia I. Mongi, E. Wantasen*, A. H. S. Salendu, M. Manese \\ FakultasPeternakanUniversitas Sam Ratulangi Manado, 95115
}

\begin{abstract}
ABSTRAK
Daging sapi merupakan salah satu produk peternakan sumber protein yang mudah ditemukan di pasar modern maupun pasar tradisional. Perilaku konsumen adalah studi tentang pembuatan keputusan. Karakteristik konsumen adalah bagian dari perilaku konsumen sehingga perusahaan yang menjual produk perlu mengenal karakteristik konsumen dan model keputusan yang dilakukan oleh konsumen serta berinovasi pada atribut daging sapi sehingga dapat menarik minat konsumen untuk membeli. Responden dalam penelitian ini berjumlah 100 yang ditentukan dengan metode non probability sampling selanjutnya menggunakan analisis deskriptif melalui kesioner untuk mengetahui karakteristik konsumen. Hasil penelitian menunjukan bahwa karakteristik konsumen daging sapi di Transmart Carrefour Star Square Manado didominasi oleh konsumen wanita sebagian besar adalah ibu rumah tangga dengan usia rata-rata lebih dari 40 tahun, pendapatan perbulan diatas 3 juta dengan tingkat pendidikan menengah hingga perguruan tinggi.
\end{abstract}

Kata Kunci :Daging sapi, karakteristik konsumen, atribut daging sapi

*Korespodensi (corresponding author)

Email : erwinwantasen@yahoo.co.id
ABSTRACT

CONSUMERS CHARACTERISTICS IN PURCHASING BEEF IN MANADO CITY (Case Study On Transmart Carrefour Star Square Manado).Beef is one of the products farm source of protein easily found in the modern market and traditional markets. Consumer behavior is the study of decision making.Consumer characteristics are part of consumer behavior so companies that sell products need to recognize consumer characteristics and decision models made by consumers and innovate on beef attributes so that they can attract consumers to buy. Respondents in this stady were 100 determined by the probability of sampling non next using descriptive analysis through the questionnaire to know the types of buyers. The results showed that the types of buyers of beef in transmart Carrefour star square manado dominated by consumers women are mostly housewives with average ages of more than 40 years, monthly income on 3 million with the education level medium to collage.

Keywords : Beef, consumer characteristics, beef attribute 


\section{PENDAHULUAN}

Protein dibagi menjadi dua kelompok, yaitu protein hewani dan nabati. Sumber protein asal hewani, yaitu daging, ikan, telur dan susu. Daging sapi merupakan salah satu produk peternakan sumber protein yang mudah ditemukan baik dipasar modern maupun di pasar tradisional. Seiring dengan perkembangan dan persaingan antara produsen daging sapi yang menuntut perbaikan disemua aspek sehingga dapat menarik perhatian dan minat para konsumen.

Karakteristik konsumen adalah bagian dari perilaku konsumen dan perusahaan yang menjual produk perlu mengenal karakteristik konsumen, model keputusan yang dilakukan oleh konsumen dan berinovasi pada atribut daging sapi sehingga dapat menarik minat konsumen untuk membeli.

Perkembangan zaman dan globalisasi mengakibatkan keberadaan modern ritel khususnya modern ritel yang merasuk dalam aktifitas keseharian masyarakat, hal ini disebabkan karena adanya perubahan pola berbelanja masyarakat (Edern, et al.2002), dimana konsumen lebeh suka berbelanja di pasar modern yang merupakan one stop shoppingdan harga yang pas dari pada di pasar tradisional yang biasanya transaksi dilakukan dengan tawar-menawar, banyaknya pelaku pasar menyebabkan besarnya margin keuntungan dan tingginya biaya pemasaran berdampak pada harga daging yang menjadi mahal (Ilham 2009) dengan kata lain pedagang daging merupakan kelompok atau lembagalembaga pemasaran yang seringkali berbeda harga satu sama lain (Yusuf dan Nulik 2008).

Salah satu supermarket yang menjual daging sapi adalah Transmart Carrefour di Star Square Manado yang adalah milik dari PT. Trans Retail Indonesia dan terletak di jalan Walter Monginsidi, Bahu, Malalayang Manado. Dengan begitu banyak supermarket di kota Manado dan persaingan yang besar dalam memasarkan serta menarik minat konsumen maka sebagai supermarket yang baru beroperasi dan menjalankan bisnisnya di kota Manado, Transmart Carrefour harus memiliki strategi bisnis dalam pemasaran untuk memberikan kepuasan kepada konsumen sehingga perusahan perlu mengetahui karakteristik konsumen daging sapi sebagai strategi untuk memasarkan produknya sehingga Karakteristik Konsumen Dalam Pembelian Daging Sapi di Kota Manado menjadi penting untuk diketahui karena dengan mengetahui karakteristik konsumen akan menjadi dasar dalam menyusun kebijakan strategis untuk menarik minat konsumen membeli daging sapi. 


\section{METODE PENELITIAN}

Penelitian ini dilakukan di Transmart Carrefour Star Square Manado pada bulan Juni 2018 sampai Agustus 2018. Hal yang melatar belakangi diambilnya Carrefour star square sebagai tempat penelitian karena supermarket ini menjual daging sapi dan supermarket ini baru beroprasi dikota manado sehingga pelu untuk mengetahui bagaimana meposisikan citra yang baik kepada konsumen melalui atribut-atribut dalam produk daging sapi yang dianggap penting oleh konsumen dan dijadikan dasar pengambilan keputusan pembeliaan.Data yang digunakan dalam penelitian ini terdiri dari dua jenis data yaitu data primer dan data sekunder. Data primer diperoleh dari hasil survey kepada konsumen daging sapi di Transmart Carrefour Star Square dan data sekunder dalam penelitian ini diperoleh dari jurnal ilmiah dan dari sumber internet. Berbagai data yang dikumpulkan dalam penelitian ini diperoleh melalui wawancara dengan menggunakan daftar pertanyaan yang berisi seperangkat pertanyaan atau pernyataan tertulis kepada responden untuk menjawabnya (Sugiyono,
2010).Populasi dalam penelitiaan ini berukuran besar dan jumlahnya tidak diketahui secara pasti, untuk menentukan jumlah sampel dari populasi yang tidak diketahui jumlahnya maka digunakan rumus (Santoso, 2017):

$$
\begin{aligned}
& n=\frac{Z^{2}}{4(M o e)^{2}} n=\frac{1,96^{2}}{4(0,05)^{2}} n=\frac{3,841}{0,04}= \\
& 96,025 \\
& \mathrm{n}=\text { jumlah sampel } \\
& \mathrm{Z}=\text { tingkat keyakinan } \\
& \text { dalam penentuan sampel } 95 \%= \\
& 1,96 \\
& \text { Moe = margin of eror atau }
\end{aligned}
$$

Hasil perhitungan didapatkan jumlah sampel sebanyak 96,025 dibulatkan menjadi 100 yang selanjutnya ditentukan dengan metode Non probability sampling menggunakan Accidental sampling. Dalam penelitian ini ada 25 atribut yang dapat mempengaruhi minat konsumen untuk membeli dapat dilihat pada tabel 1 . Artribut-atribut tersebut adalah bagian dari bauran pemasaran yang dapat menentukan kesuksesan perusahaan dalam mengejar keuntungan maksimal dengan cara meningkatkan hasil penjualan. 
Tabel 1.Atribut Daging Sapi

\begin{tabular}{cl} 
No & NamaAtribut \\
\hline 1 & Gizi \\
2 & Warna \\
3 & Tekstur \\
4 & Keterangan halal \\
5 & Ragam bagian daging \\
6 & Ragam potongan daging \\
7 & Kandungan lemak \\
8 & Keterangan kadaluarsa \\
9 & Suhu penyimpanan \\
10 & Tingkat harga \\
11 & Cara pembayaran tunai \\
12 & Cara pembayaran kartukredit \\
13 & Lokasi mudah dijangkau \\
14 & Otlet tersendiri \\
15 & Potongan harga \\
16 & Brosur \\
17 & Kemasan \\
18 & Ketersediaan tempat parker \\
19 & Kontinuitas persediaan daging \\
20 & ketersediaan toilet \\
21 & Kebersihan Lokasi penjualan \\
22 & Kecepatan pelayanan dikasir \\
23 & Pendampingan pelayanan karyawan \\
24 & Keramahan Karyawan \\
25 & Kerapihan seragam karyawan \\
\hline
\end{tabular}

\section{HASIL DAN PEMBAHASAN}

Karakteristik responden dalam penelitian ini dijelaskan berdasarkan jenis kelamin, umur, pekerjaan, pendapatan perbulan dan pendidikan terakhir.

\section{Jenis Kelamin}

Berdasarkan gambar 1, diketahui bahwa responden berjenis kelamin perempuan $100 \%$ hal ini dikarenakan pada umumnya yang membeli dan memilih bahan makanan untuk keluarga adalah seorang ibu rumah tangga, hal ini sejalan dengan hasil penelitian terdahulu (Burhanudin, 2011) dimana konsumen atau pembeli daging sapi dan sejenisnya didominasi oleh kalangan ibu-ibu rumah tangga yang berbelanja bahan makanan yang nantinya akan diolah dari bahan mentah menjadi bahan olahan untuk dikonsumsi oleh keluarga. Pemilihan daging yang baik akan dapat dipilih dan ditentukan oleh mereka yang sudah terbiasa membeli. 


\section{Jenis Kelamin}

Gambar 1.Karakteristik Responden Berdsarkan Jenis Kelamin

Umur

Berdasarkan gambar 2, diketahui bahwa responden yang paling banyak berumur diatas 40 tahun yang artinya sebagian besar konsumen daging sapi adalah konsumen dewasa yang memahami produk pangan yang dibeli untuk dikonsumsi. Hal ini sejalan dengan hasil penelitian sebelumnya (Hamzan, 2013).

Umur masyarakat merupakan salah satu faktor internal yang berpengaruh secara signifikan terhadap pembelian daging. Nilai score umur masyarakat yang bertanda positif yang menunjukkan bila umur masyarakat berada pada usia produktif (18 sampai dengan 60 tahun) maka peluang masyarakat dalam pembelian daging akan semakin besar, demikian sebaliknya jika usia masyarakat sudah tidak produktif maka cenderung dalam pembelian daging akan semakin kecil (I Gusti et al., 2015)

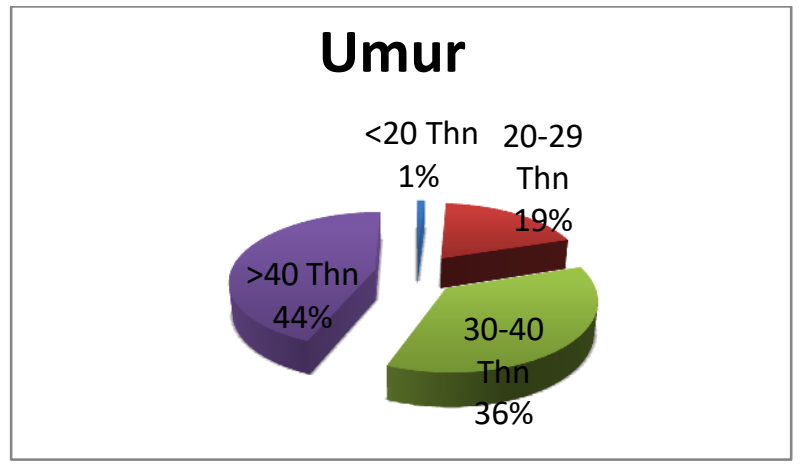

Gambar 2.Karakteristik Responden Berdasrkan Umur 


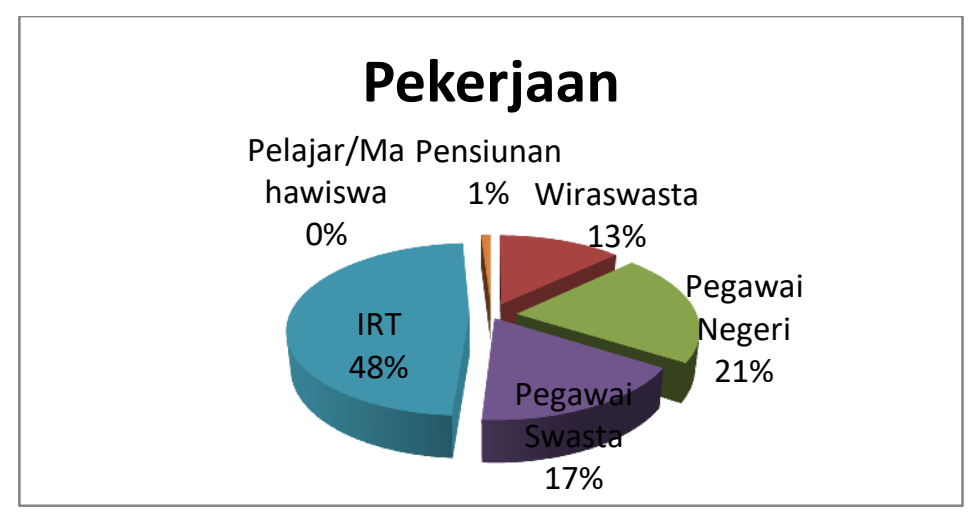

\section{Gambar 3.Karakteristik Responden Berdasarkan Pekerjaan}

\section{Pekerjaan}

Berdasarkan gambar 3, diketahui bahwa responden sebanyak $48 \%$ memiliki jenis pekerjaan sebagai pengurus rumah tangga yang benar-benar memilih bahan makanan atau produk pangan untuk seluruh anggota keluarga, karena ibu rumah tangga bertanggung jawab terhadap pemenuhan gizi keluarga, hal ini sejalan dengan hasil penelitian sebelumnya (Hamzan 2013) dan sejalan dengan karakteristik responden yang pertama yaitu jenis kelamin dimana yang mendominasi adalah konsumen wanita atau ibu-ibu rumah tangga.

\section{Pendapatan Perbulan}

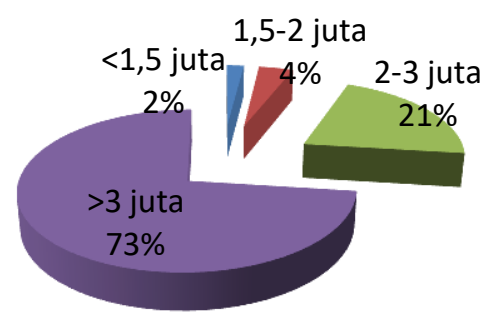

Gambar 4.Karakteristik Responden Berdasarkan Pendapatan Perbulan 


\section{Pendapatan Perbulan}

Diketahui dari gambar 4 bahwa responden yang berpendapatan >3juta sebanyak $73 \%$ hal ini dikarenakan harga daging sapi yang relative lebih mahal dibandingkan dengan harga-harga daging atau bahan pangan penggantinya.

\section{Pendidikan Terakhir}

Diketahui dari gambar 5 bahwa responden yang paling dominan memiliki tingkat pendidikan SMA sebanyak $47 \%$ dan S1 sebanyak $31 \%$ yang artinya konsumen daging sapi pada umumnya memiliki pendidikan yang cukup untuk mengetahui produk yang bergizi untuk diolah dan dikonsumsi oleh keluarga. Sayuti dan Efendi (2004) Menyatakan bahwa pendidikan merupakan factor penting yang berpengaruh terhadap posisi social dan ekonomi seseorang. Pendidikan berkemampuan untuk melihat nilai makanan. Hal ini jalan dengan hasilpenelitian sebelumnya oleh (Tarigan 2006

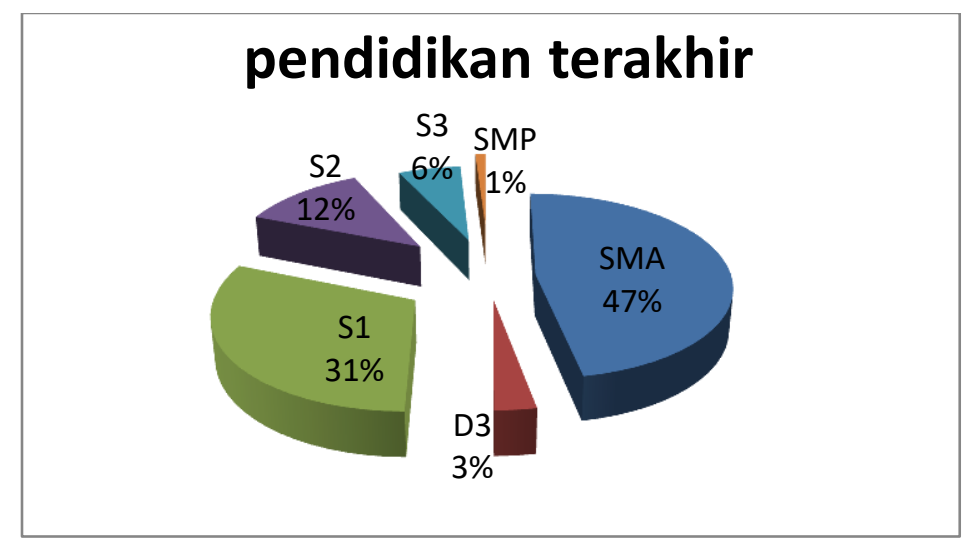

Gambar 5, Karakteristik Responden Berdasarkan Pendidikan Terakhir 


\section{KESIMPULAN}

Karakteristik responden konsumen daging sapi di Transmart Carrefour Star Square Manado didominasi oleh konsumen wanita yang sebagian besar adalah ibu rumah tangga dengan usia ratarata lebih dari 40 tahun dan pendapatan perbulan diatas 3 juta dengan tingkat pendidikan menengah hingga pendidikan tinggi (SMA dan Sarjana).

\section{DAFTAR PUSTAKA}

Burhanudin, A. 2011. Analisis perilaku konsumen pada pembeliaan daging ayam ras (Broiler Chicken) di pasar tradisional dan pasar modern kota jember. Skripsi. Universitas Jember.

Ederm T., S. Joffre dan J. Louviere. 2002. The impact of brand credibility on consumer price sensitivity. Journal international of marketing. $19: 1-19$

Hamzan, W. dan B. Rahanatha. 2013. Hubungan variable demografi dengan respon konsumen terhadap ikaln merk top coffe di Kota Den pasar. Jurnal Ekonomi, 2(9) : 10361052.

I Gusti N. Y. P., M. Sudarmadan A. A.A Wulandira. 2015. Faktor-faktor yang mempengaruhi masyarakat membeli daging ayam broiler dikabupaten bangli. E. Jurnal Agribisnis dan Agrowisata. 4(1):47-55

Ilham, N. 2009. Kebijakan pengendalian harga daging sapi nasional. Analisis Kebijakan Pertanian. 3:211-221.

Santoso, S. 2017. Statistik multivariant dengan SPSS. PT. Elix Media Kemputindo. Jakarta.

Sugiyono. 2010. Metode penelitian pendidikan pendekatan kuantitatif, kualitatif, dan R\&D. Bandung: Alfabeta.

Sayuti, K dan Efendi. 2004. Pola konsumsi pangan sumber protein mahasiswa Universitas Andalas. Jurnal Stigma (2) : 236-243

Tarigan R. 2006. Pengaruh tingkat pendidikan terhadap tingkat pendapatan perbandingan antara empat hasil penelitian. Jurnal Wawasan 11(3).

Yusuf. dan J. Nulik. 2008. kelembagaan ternak sapi potong di Timor Barat, Nusa Tengga Timor. Jurnal Pengkajian dan Pengembangan Teknologi Pertanian,11 (2) : 133145. 